\title{
PENGARUH VOLUME RUANG BAKAR SEPEDA MOTOR TERHADAP PRESTASI MESIN SEPEDA MOTOR 4-LANGKAH
}

\author{
Untung Surya Dharma ${ }^{1^{*}}$, Totong Heru Wahyudi² \\ Program Studi Teknik Mesin, Fakultas Teknik, Universitas Muhammadiyah Metro \\ Jl. Ki Hajar Dewantara 15 A Metro, Lampung ${ }^{1,2)}$ \\ untungsdh@yahoo.co.id ${ }^{1}$
}

\begin{abstract}
Abstrak
Banyak macam cara digunakan untuk meningkatkan prestasi mesin sepeda motor bensin. Salah satunya dengan meningkatkan perbandingan kompresi yaitu dengan jalan memperpanjang langkah torak (stroke). Tujuan dari penelitian ini untuk mengetahui daya dan efisiensi termal serta konsumsi bahan bakar yang terjadi setelah dilakukan modififikasi dengan cara memperpanjang langkah torak sebesar $2 \mathrm{~mm}$. Pengujian dilakukan pada mesin sepeda motor bensin $110 \mathrm{cc}$ dengan spesifikasi teknis standar dan berbahan bakar bensin. Dalam perhitungan untuk mendapatkan prestasi mesin dilakukan dengan beberapa cara pengujian, yaitu perhitungan volume ruang bakar, rasio kompresi, perbandingan kalor spesifik, efisiensi thermal, tekanan efektif rata-rata, dan daya spesifik, dan pengujian konsumsi bahan bakar (road test dan stasioner), pengujian akselerasi, dan pengujian kecepatan maksimum. Dari cara meningkatkan unjuk kerja mesin yang telah dilakukan, proses memperpanjang volume ruang bakar (stroke) menunjukkan pengaruh yang lebih besar, dari volume standar sebesar $97,1 \mathrm{~cm}^{3}$ dengan daya 8009 PS sebelum dimodifikasi, setelah dimodifikasi menjadi menjadi $1049 \mathrm{~cm}^{3}$ dengan daya 10668 PS sehingga mengalami peningkatan volume ruang bakar, 7,8 $\mathrm{cm}^{3}$ dan daya sebesar 2659 PS, efesiensi thermal mesin, sebelum modifikasi sebesar 0,5756 dan setelah modifikasi mencapai 0,6713, konsumsi BB berdasarkan pengujian road test dengan jarak tempuh $50 \mathrm{~km} /$ jam sebelum modifikasi 47,33 mL meningkat menjadi $50 \mathrm{~mL}$ sesudah dimodifikasi, pada pengujian stasioner sebelum modifikasi $72 \mathrm{~mL}$ meningkat menjadi $74 \mathrm{~mL}$ dikarenakan volume ruang bakar yang bertambah dan membutuhkan konsumsi BB yang lebih banyak.
\end{abstract}

Kata kunci: Prestasi Mesin, kompresi, stroke, pengujian

\section{Pendahuluan}

Di Indonesia sepeda motor merupakan alat transportasi yang paling banyak dipakai untuk sarana trasportasi. Daya yang dibangkitkan pada sepeda motor berasal dari pembakaran antara bahan bakar dengan oksigen dari udara luar. Gas pembakaran yang dihasilkan oleh proses tersebut mampu menggerakkan piston yang kemudian diteruskan melalui connecting rod menuju crankshaft.

Dalam upaya mendapatkan daya yang lebih besar, dapat dilakukan perubahan atau modifikasi pada bagian mesin. Salah satunya adalah dengan memodifikasi ruang bakar, sehingga rasio kompresi berubah $\left[\begin{array}{lll}1 & \& & 2\end{array}\right]$. Ruang bakar berfungsi sebagai tempat pembakaran campuran bahan bakar dengan udara yang telah dikompresikan oleh torak didalam silinder. Apabila bahan bakar dan udara yang dikompresikan lebih banyak akan menghasilkan daya yang lebih besar [3]. Sehingga pada penelitian ini akan dilakukan modifikasi mesin yang di sebut dengan modifikasi stroke, yaitu dengan cara merubah panjang langkah torak untuk memperoleh volume ruang bakar yang lebih besar sehingga akan didapat perbandingan kompresi yang lebih besar, dengan tujuan untuk mendapatkan daya yang lebih besar. 
Namun dengan penambahan volume ruang bakar yang lebih besar akan berpengaruh pada penggunaan bahan bakar. Begitu juga perubahan tekanan dan efesiensi termal mesin yang nantinya akan berpengaruh terhadap prestasi mesin, sehingga penelitian ini diharapkan mampu menjelaskan seberapa besar pengaruh volume ruang bakar terhadap prestasi mesin sepeda motor bensin $110 \mathrm{cc}$ tersebut

\section{Tinjauan Teoritis}

Mesin 4-langkah adalah mesin pembakaran dalam yang dalam satu siklus pembakaran terjadi empat langkah piston dan dua putaran poros engkol. Empat langkah tersebut meliputi, langkah hisap (pemasukan), kompresi, tenaga, dan langkah buang yang secara keseluruhan memerlukan dua putaran poros engkol (crankshaft) per satu siklus pada mesin bensin atau mesin diesel [1]
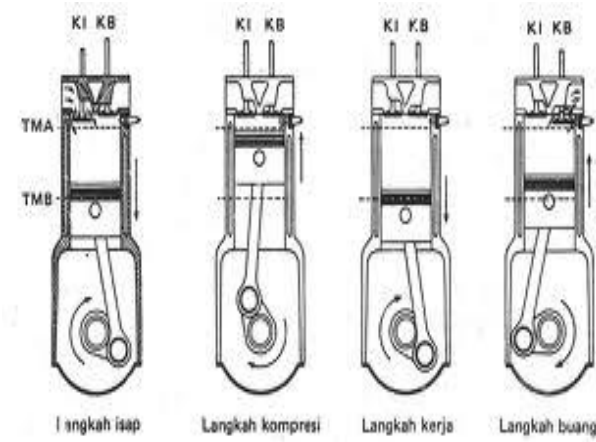

Gambar 1. Siklus Kerja Motor 4-Langkah

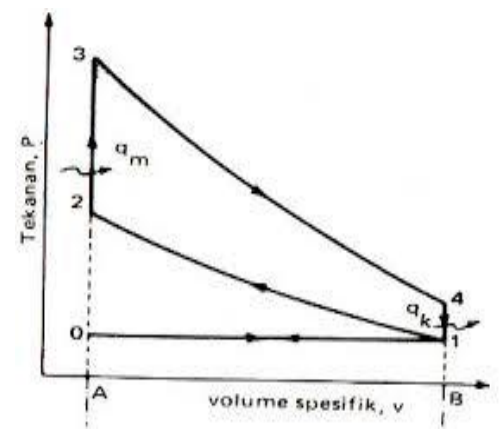

Gambar 2 Diagram P vs. V siklus dari volume konstan

Dimana dari gambar diketahui :

$\mathrm{P}=$ tekanan fluida kerja, $\mathrm{kg} / \mathrm{cm}^{3}$

$\mathrm{V}=$ volume spesifik, $\mathrm{m}^{3} / \mathrm{kg}$

$\mathrm{q}_{\mathrm{m}}=$ laju aliran kalor yang di masukkan, $\mathrm{kcal} / \mathrm{kg}$ $\mathrm{q}_{\mathrm{k}}=$ laju aliran kalor yang di keluarkan, $\mathrm{kcal} / \mathrm{kg}$

$\mathrm{V}_{\mathrm{L}}=$ volume langkah torak, $\mathrm{m}^{3}$ atau $\mathrm{cm}^{3}$

$\mathrm{V}_{\mathrm{s}}=$ volume sisa, $\mathrm{m}^{3}$ atau $\mathrm{cm}^{3}$

Menurut Aris Munandar [4] Siklus udara volume-konstan (siklus otto). Siklus ini dapat di gambarkan dengan grafik $P$ vs $v$ seperti terlihat pada gambar 2, sifat ideal yang dipergunakan serta keterangan mengenai proses siklusnya adalah sebagai berikut :

1. Fluida kerja di anggap sebagai gas ideal dengan kalor spesifik yang konstan.

2. Langkah hisap (0-1).

Piston bergerak dari TMA ke TMB dengan katup masuk terbuka dan katup buang tertutup. Hal ini menciptakan pertambahan volume di ruang bakar, yang pada giliranya menciptakan ruang hampa. Tekanan diferensial yang di hasilkan melalui sistem pemasukan dari tekanan udara atmosfer ke vakum di dalam silinder menyebabkan udara di dorong masuk ke dalam silinder. Ketika udara lewat melalui sistem masukan, bahan bakar dimasukkan kedalamnya sesuai dengan jumlah yang diinginkan dengan bantuan injektor bahan bakar atau karburator.

3. Langkah kompresi (1-2).

Ketika piston mencapai TMB, katup masuk tertutup dan piston bergerak kembali ke TMA dengan seluruh katup dalam kondisi tertutup. Kompresi campuran udara-bahan bakar ini, meningkatkan temperatur dan tekanan di dalam silinder. Menjelang ahir langkah kompresi, busi dinyalakan dan pembakaran di mulai.

4. Proses pembakaran volume-konstan (2-3).

Pembakaran campuran udara-bahan bakar terjadi sangat singkat tetapi panjangnya waktu terbatas dengan piston dekat TMA. Diawali menjelang ahir langkah kompresi sedikit sebelim TMA dan berakhir ke langkah daya sedikit sesudah TMA. Pembakaran mengubah kompresi campuran gas menjadi produk buangan dan meningkatkan temperatur di dalam silinder ke suatu nilai puncak yang sangat tinggi. Hal ini, pada giliranya, akan meningkatkan tekanan di dalam silinder ke suatu nilai puncak yang sangat tinggi

5. Langkah kerja (3-4). 
Dengan seluruh katup tertutup, tekanan tinggi yang di ciptakan oleh proses pembakaran mendorong piston menjauh dari TMA. Ini adalah langkah yang menghasilkan kerja keluaran dari siklus motor. Saat piston bergerak dari TMA ke TMB, volume silinder bertambah, menyebabkan turunya tekanan dan temperatur.

6. Proses pembuangan (4-1).

Akhir dari langkah daya, katup buang terbuka dan pengurasan (blowdown) keluaran terjadi.

7. Langkah buang (1-0).

Pada saat piston mencapai TMB, lengkaplah pembilasan keluaran, tetapi silinder masih penuh dengan gas buang. Dengan katup buang yang terbuka, piston sekarang bergerak dari TMB ke TMA pada langkah buang. Ketika piston mendekati TMA maka katup masuk mulai membuka dan katup buang mulai menutup dan akhirnya secara penuh tertutup kadang-kadang sesudah TMA. Periode dimana katup buang dan katup masukan kedua-duanya di buka di sebut dengan tumpang tindih katup (valve overlap).

8. Siklus di anggap tertutup.

siklus ini berlangsung dengan fluida kerja yang sama, atau gas yang berada di dalam silinder pada titik 1 dapat di keluarkan dari dalam silinder pada waktu langkah buang, tetapi pada langkah hisap berikutnya akan masuk sejumlah fluida kerja yang sama.

Prestasi mesin biasanya dinyatakan dengan efisiensi thermal karena pada motor bakar 4 langkah selalu berhubungan dengan pemanfaatan energy panas. Efisiensi thermal adalah perbandingan energi berguna dengan energi yang diberikan. Prestasi mesin dapat juga dinyatakan dengan daya keluran dan pemakaian bahan bakar spesifik engkol yang dihasilkan mesin. Daya output engkol menunjukan daya output yang berguna untuk menggerakan sesuatu atau beban. Sedangkan pemakaian bahan bakar spesifik engkol menunjukan seberapa efisien suatu mesin menggunakan bahan bakar yang disuplai untuk menghasilkan kerja. Prestasi mesin sangat erat hubungannya dengan parameter operasional, besar kecilnya harga parameter operasinal akan menentukan tinggi rendahnya prestasi mesin yang dihasilkan.

\section{Perhitungan prestasi mesin}

\section{Volume Silinder}

Volume silinder adalah besarnya volume langkah (piston displacement) di tambah volume ruang bakar. Volume langkah di hitung dari volume di atas piston di TMB sampai garis TMA. Sedangkan volume ruang bakar dihitung volume di atas piston saat posisi piston berada di TMA, juga di sebut volume sisa. Besarnya volume langkah atau isi langkah piston adalah luas lingkaran dikalikan panjang piston [5] dengan persamaan :

$$
\mathrm{V}_{\mathrm{L}}=\frac{\pi}{4} \cdot \mathrm{D}^{2} . \mathrm{L}
$$

Dimana,

$\mathrm{V}_{\mathrm{L}}=$ Volume Langkah $\left(\mathrm{mm}^{3}\right)$

$\mathrm{D}=$ Diameter Silinder $(\mathrm{mm})$

$\mathrm{L}=$ Panjang Langkah Piston (mm)

\section{Efisiensi Termal}

Perbandingan kompresi ialah perbandingan antara volume silinder dan volume ruang bakar atau ruang kompresi [6], dinyatakan :

$$
\mathrm{r}=\frac{V \max }{V \min }
$$

Dimana :

$\mathrm{r} \quad=$ rasio kompresi

Vmak $=$ volume maksimum $\left(\mathrm{mm}^{3}\right)$

Vmin $=$ volume minimum $\left(\mathrm{mm}^{3}\right)$

Untuk perbandingan kalor spesifik udara pada volume tetap[3] dengan Qout ialah panas yang di keluarkan dari system pembakaran, dengan demikian persamaan volume konstan dengan $c_{v}$ ialah panas spesifik udara pada volume konstan yang terjadi pada siklus 1-2 dan 3-4 yaitu terjadinya proses adiabatik. Sedangkan $Q_{\text {in }}$ ialah panas yang ditambahkan dari system pembakaran, dengan demikian persamaan tekanan konstan dengan $c_{p}$ ialah panas spesifik udara pada tekanan konstan yang terjadi pada siklus 2-3 dan 4-1 yaitu terjadinya proses isotermik dinyatakan : 


$$
\mathrm{k}=\frac{\mathrm{C}_{\mathrm{P}}}{\mathrm{C}_{\mathrm{V}}}
$$

Dimana : $\mathrm{k}=$ perbandingan kalor spesifik udara pada volume tetap

$\mathrm{Cp}=$ panas spesifik udara pada tekanan konstan (kJ/kg.K)

$\mathrm{Cv}=$ panas spesifik udara pada volume konstan $(\mathrm{kJ} / \mathrm{kg} . \mathrm{K})$

\section{Untuk efesiensi thermal[3] dinyatakan :}

$$
\prod_{\text {th. }}=1-\frac{1}{\mathrm{r}^{\mathrm{k}-1}}
$$

Dimana :

$$
\begin{aligned}
& \eta_{\text {th. }}=\text { efisiensi termal } \\
& \mathrm{r}=\text { rasio kompresi } \\
& \mathrm{k}=\underset{\text { perbandingan kalor spesifik udara pada }}{\text { volume tetap }}
\end{aligned}
$$

\section{Tekanan Efektif rata-rata}

Konsumsi Bahan Bakar (BFC) [7],

$$
\mathrm{BFC}=\frac{\mathrm{V}_{f}}{\mathrm{t}} \cdot \frac{3600}{1000}
$$

\section{Dimana :}

$\mathrm{BFC}=$ konsumsi bahan bakar (L/jam)

$V_{f}=$ konsumsi bahan bakar selama $\mathrm{t}$ detik $(\mathrm{mL})$

$\mathrm{t}=$ interval waktu pengukuran konsumsi bahan bakar (detik)

Laju aliran massa bahan bakar [4],

$$
\mathrm{m}=\underline{\mathrm{BFC}} \cdot \underline{\rho}
$$

Dimana :

ḿ = laju aliran massa bahan bakar $(\mathrm{kg} / \mathrm{s})$

$\mathrm{BFC}=$ konsumsi bahan bakar $(\mathrm{L} / \mathrm{jam})$

$\rho \quad=$ massa jenis bahan bakar $\left(\mathrm{kg} / \mathrm{m}^{3}\right)$

\section{Panas yang masuk ke dalam pembakaran}

Nilai kalor bawah (Low Heating Value,LHV), merupakan nilai kalor bahan bakar tanpa panas laten yang berasal dari pengembunan uap air. Umumnya kandungan hidrogen dalam bahan bakar cair berkisar $15 \%$ yang berarti dalam satu satuan bahan bakar 0,15 bagian merupakan hidrogen. Uap air yang terbentuk pada proses pembakaran dapat pula berasal dari kandungan air yang memang sudah ada didalam bahan bakar (moisture). Panas laten pengkondensasian uap air pada tekanan parsial $20 \mathrm{kN} / \mathrm{m}^{2}$ (tekanan yang umum timbul pada gas buang) adalah sebesar $2400 \mathrm{kj} / \mathrm{kg}, \quad \mathrm{M}=$ Persentase kandungan air dalam bahan bakar (moisture) Dalam perhitungan efisiensi panas dari motor bakar, dapat mengggunakan nilai kalor bawah (LHV). Namun dapat juga menggunakan nilai kalor atas (HHV) karena nilai tersebut umumnya lebih cepat tersedia. Peraturan pengujian berdasarkan ASME (American of Mechanical Enggineers) menentukan penggunaan nilai kalor atas (HHV), Sedangkan peraturan SAE (Society of Automotive Enggineers) menentukan penggunaan nilai kalor bawah (LHV) adalah $44400 \mathrm{~kJ} / \mathrm{kg}$, [8]

$$
\mathrm{Q}_{\text {in }}=\mathrm{LHV} \cdot \mathrm{m} \bullet \mathrm{t}
$$

Dimana :

$\mathrm{Q}_{\text {in }}=$ panas yang masuk dalam pembakaran (kJ)

$\mathrm{LHV}=$ nilai kalor bawah bahan bakar $(\mathrm{kJ} / \mathrm{kg})$

ḿ = laju aliran massa bahan bakar $(\mathrm{kg} / \mathrm{s})$

$\mathrm{t}=$ waktu pengujian (detik)

\section{kerja bersih per-siklus[3],}

$$
\mathrm{W}_{\text {net }}=\prod_{\text {th }} \cdot \mathrm{Q}_{\text {in }}
$$

Dimana :

$\mathrm{W}_{\text {net }}=$ kerja bersih per-siklus $(\mathrm{kJ})$

$\eta_{\text {th }}=$ efisiensi termal

$\mathrm{Q}_{\text {in }}=$ panas yang masuk dalam pembakaran $(\mathrm{kJ})$

\section{Tekanan efektif rata-rata}

Adalah besarnya rata - rata tekanan yang dihasilkan dari pembakaran campuran bahan bakar [3]. Dalam pengujian ini diasumsikan gas buang yang keluar dari knalpot mesin uji masih mengandung uap air (uap air yang terbentuk dari proses pembakaran bahan bakar yang belum sempat mengalami kondensasi didalam silinder sebelum langkah buang terjadi) sehingga kalor laten kondensasi uap air tidak diperhitungkan sebagai nilai kalor pembakaran bahan bakar.

Tekanan efektif rata-rata dinyatakan : 


$$
P_{e}=\frac{\text { Wnet }}{V}
$$

Dimana :

$\mathrm{P}_{\mathrm{e}} \quad=$ tekanan efektif rata rata $\left(\mathrm{N} / \mathrm{m}^{2}\right)$

Wnet $=$ kerja bersih dalam satu siklus $(\mathrm{kJ})$

$\mathrm{V}=$ volume $\left(\mathrm{m}^{3}\right)$

\section{Daya Spesifik Motor}

Daya spesifik motor ialah daya usaha yang dapat di berikan untuk tiap-tiap $\mathrm{cm}^{2}$ luas dinding silinder motor, [1] dinyatakan

$\mathrm{Ne}=\underline{\mathrm{P}_{\mathrm{e}} \cdot \mathrm{V}_{\mathrm{L}} \cdot \mathrm{a} \cdot \mathrm{n} \cdot \mathrm{z}}$

Dimana,

$\mathrm{Ne}=$ daya motor $(\mathrm{PS})$

$\mathrm{V}_{\mathrm{L}}=$ volume langkah $\left(\mathrm{cm}^{3}\right)$

$\mathrm{a}=$ siklus per-langkah

$\mathrm{Pe}=$ tekana efektif rata-rata $\left(\mathrm{kg} / \mathrm{cm}^{2}\right)$

$\mathrm{N}=$ putaran $(\mathrm{rpm})$

$\mathrm{z}=$ jumlah silinder

\section{Persentase Pemakaian Bahan Bakar}

Persentase penggunaan bahan bakar sebelum dan sesudah modifikasi dapat di hitung dengan menggunakan persamaan sebagai berikut

Konsumsi BB $=\frac{\text { Setelah }- \text { sebelum }}{\text { sebelum }} \times 100 \%$

\section{Dimana :}

Konsumsi BB = konsumsi bahan bakar (liter)

Setelah $=$ setelah modifikasi

sebelum $=$ sebelum modifikasi

\section{Metode Penelitian}

\section{Tempat penelitian}

Tempat penelitian di lakukan di Laboraturium Teknik Mesin Universitas Muhamadiyah Metro dan di Jalan komplek persawahan SMAN 5 Kota Metro.

\section{Spesifikasi Sepeda Motor Yang Digunakan}

Spesifikasi sepeda motor yang di gunakan adalah sepada motor 110 cc dengan spesifikasi sebagai berikut :

Type mesin : 4-langkah, SOHC pendingin udara

Diameter x langkah : 50 x 49,5 mm
Volume Langkah $\quad: 97,1 \mathrm{cc}$

Perbandingan kompresi $\quad: 9,0: 1$

Daya maksimum $\quad: 7,3 \mathrm{PS} / 8000 \mathrm{rpm}$

Torsi maksimum : : $0,74 \mathrm{kgf.m} / 6000 \mathrm{rpm}$

Kopling : manual

Susunan silinder $\quad: \quad$ silinder tunggal

mendatar

Gigi trasmisi $\quad: 4$ kecepatan

Pola pengoperan gigi : N-1-2-3-4

Berat isi : $99,8 \mathrm{~kg}$

Sistem pengapian : AC-CDI, Magneto

\section{Prosedur pengujian}

Pengujian parameter prestasi mesin sepeda adalah

1. Konsumsi bahan bakar sebelum dan sesudah modifikasi

a. Pengujian berjalan pada kecepatan konstan $(50 \mathrm{~km} / \mathrm{jam})$.

Pengujian ini untuk mengetahui konsumsi bahan bakar sebelum dan sesudah di modifikasi. Pengujian road test dilakukan pada cuaca dan kondisi yang sama dengan beban kendaraan dan cara berkendara yang juga sama. Data pada pengujian road test adalah data konsumsi bahan bakar (liter) pada kecepatan konstan $(50 \mathrm{~km} / \mathrm{jam})$ untuk jarak $1 \mathrm{~km}$ dan data akselerasi dari keadaan diam.

b. Pengujian stasioner pada putaran 1500 rpm, $2500 \mathrm{rpm}, 4000 \mathrm{rpm}$ selama 10 menit

Pengujian ini dilakukan untuk melihat perbandingan karakteristik mesin sepeda motor anatar sebelum di modifikasi dan sesudah di modifikasi. Pengujian ini dilakukan pada putaran $1500 \mathrm{rpm}, 2500 \mathrm{rpm}, 4000 \mathrm{rpm}$ selama 10 menit dengan membandingkan konsumsi bahan bakar yang terpakai dengan konsumsi bahan bakar pada keadaan stasioner.

2. Akselerasi dari keadaan diam 0-20 $\mathrm{km} / \mathrm{jam}, 0-40 \mathrm{~km} / \mathrm{jam}$ 0-60 km/jam, 0-80 $\mathrm{km} / \mathrm{jam}$ (detik)

Pengujian akselerasi ini di lakukan pada saat sebelum dan sesudah modifikasi. Motor yang telah dinyalakan dalam keadaan berhenti $(0 \mathrm{~km} / \mathrm{jam})$.ketika gas 
mulai di tekan, stopwatch mulai di aktifkan untuk mencatat waktu tempuhnya. Pada perpindahan gigi pertama, kecepatan sepeda motor dari $0-20 \mathrm{~km} / . j a m$ lalu perpindahan gigi yang kedua pada kecepatan 20-40 $\mathrm{km} / \mathrm{jam}$ dan ketika mencapai kecepatan $40 \mathrm{~km} / \mathrm{jam}$ langsung melakukan pergantian gigi ketiga. Perubahan kecepatan sekaligus diikuti dengan mengaktifkan stopwatch hingga selesai.

\section{Hasil Dan Pembahasan}

\section{A. Perhitungan Daya Mesin Sebelum Modifikasi}

Tabel 1. Data pengukuran sebelum mesin dimodifikasi

\begin{tabular}{|c|l|l|}
\hline No & \multicolumn{1}{|c|}{ Item } & \multicolumn{1}{|c|}{$\begin{array}{c}\text { Nilai Pengukuran } \\
(\mathbf{m m})\end{array}$} \\
\hline 1 & Diameter piston & $50 \mathrm{~mm}$ \\
\hline 2 & $\begin{array}{l}\text { Panjang langkah torak } \\
\text { (TMB) }\end{array}$ & $49,5 \mathrm{~mm}$ \\
\hline 3 & $\begin{array}{l}\text { Panjang langkah torak } \\
\text { (TMA) }\end{array}$ & $5,5 \mathrm{~mm}$ \\
\hline 4 & Rasio kompresi & $9: 1$ \\
\hline 5 & Putaran & $8000 \mathrm{rpm}$ \\
\hline 6 & Konsumsi bahan bakar & $47 \mathrm{~mL}$ \\
\hline 7 & Waktu pengujian & $426 \mathrm{det}$ \\
\hline
\end{tabular}

Volume ruang bakar/volume maksimum (saat piston posisi TMB)

$\mathrm{V}_{\mathrm{Lmak}}=\frac{\pi}{4} \cdot \mathrm{D}^{2} \cdot \mathrm{L}$

$\mathrm{V}_{\text {Lmak }}=\frac{\pi}{4} \cdot 50^{2} \mathrm{~mm} \cdot 49,5 \mathrm{~mm}$

$\mathrm{V}_{\text {Lmak }}=97143,75 \mathrm{~mm}^{3}$

$\mathrm{V}_{\mathrm{L} \text { mak }}=97,1 \mathrm{~cm}^{3}$

Volume ruang bakar/volume minimum (saat piston posisi TMA)

$\mathrm{V}_{\mathrm{Lmin}}=\frac{\pi}{4} \cdot \mathrm{D}^{2} \cdot \mathrm{L}$

$\mathrm{V}_{\text {Lmin }}=\frac{\pi}{4} \cdot 50^{2} \mathrm{~mm} \cdot 5,5 \mathrm{~mm}$

$\mathrm{V}_{\mathrm{Lmin}}=10793,75 \mathrm{~mm}^{3}$

$\mathrm{V}_{\mathrm{Lmin}}=10,7 \mathrm{~cm}^{3}$

\section{Perbandingan kompresi,}

$\mathrm{r}=\frac{V \max }{V \min }$

$\mathrm{r}=\frac{97143,75 \mathrm{~mm}}{10793,75 \mathrm{~mm}}$ $r=9$

Perbandingan kalor spesifik udara pada volume tetap,

$\mathrm{k}=\frac{\mathrm{C}_{\mathrm{p}}}{\mathrm{C}_{\mathrm{v}}}$

$\mathrm{k}=\frac{1,005}{0,718}$

$\mathrm{k}=1,39$

Efesiensi thermal ,

$\eta_{\text {th. }}=1-\frac{1}{\mathrm{r}^{\mathrm{k}-1}}$

$\eta_{\text {th. }}=1-\frac{1}{9^{1,39-1}}$

$\eta_{\text {th. }}=0,5756$

\section{Tekanan Efektif rata-rata}

- Konsumsi Bahan Bakar (BFC),

$\mathrm{BFC}=\frac{\mathrm{v} f(\mathrm{~mL})}{t(\text { det })}\left\{\frac{3600(\text { det })}{1(j \mathrm{am})}\right\} \bullet\left\{\left(\frac{1 L}{1000 \mathrm{~mL}}\right)\right.$

$\mathrm{BFC}=\frac{47 \mathrm{~mL}}{426 \mathrm{det}} \cdot \frac{3600}{1000}$

$\mathrm{BFC}=\frac{169200 \mathrm{~L}}{426000 \mathrm{jam}}$

$\mathrm{BFC}=0.39 \mathrm{~L} / \mathrm{jam}$

- Laju aliran massa bahan bakar

$\mathrm{m}=\frac{\mathrm{BFC}}{3600} \cdot \frac{\rho}{1000}$

$\mathrm{m}=1,084^{-4} \mathrm{~L} / \mathrm{det} \cdot 0,68 \mathrm{~kg} / \mathrm{dm}^{3}$

$\mathrm{m}=7,367 \cdot 10^{-5} \mathrm{~kg} / \mathrm{s}$

- Panas yang masuk ke dalam pembakaran

$\mathrm{Q}_{\text {in }}=\mathrm{LHV} \cdot \mathrm{m}$

$\mathrm{Q}_{\text {in }}=44400 \mathrm{~kJ} / \mathrm{kg} \cdot 7,367.10^{-5} \mathrm{~kg} / \mathrm{s} \cdot 426$

det

$\mathrm{Q}_{\text {in }}=1393,3 \mathrm{Kj}$

- kerja bersih per-siklus, 


$$
\begin{aligned}
& \mathrm{W}_{\text {net }}=\prod_{\text {th }} \cdot \mathrm{Q}_{\text {in }} \\
& \mathrm{W}_{\text {net }}=0,5756 \cdot 1393,3 \mathrm{~kJ} \\
& \mathrm{~W}_{\text {net }}=801,9 \mathrm{~kJ}
\end{aligned}
$$

- Tekanan efektif rata-rata

$$
\begin{aligned}
& \mathrm{P}_{\mathrm{e}}=\frac{\text { Wnet }}{\mathrm{V}} \\
& \mathrm{P}_{\mathrm{e}}=\frac{801,98 \mathrm{~kJ}}{86,4 \mathrm{~cm} 3} \\
& \mathrm{P}_{\mathrm{e}}=9,28 \mathrm{kN} / \mathrm{cm}^{2}
\end{aligned}
$$

\section{Daya Spesifik Motor,}

$$
\begin{aligned}
& \mathrm{Ne}=\frac{\mathrm{P}_{\mathrm{e}} \cdot \mathrm{V}_{\mathrm{L}} \cdot \mathrm{a} \cdot \mathrm{n} \cdot \mathrm{z}}{450000} \\
& \mathrm{Ne}=\frac{9280 \mathrm{~kg} / \mathrm{cm}^{2} \cdot 97 \cdot 1 \mathrm{~cm}^{3} \cdot 1 / 2 \cdot 8000.1}{450000} \\
& \mathrm{Ne}=8009 \mathrm{PS}
\end{aligned}
$$

\section{B. Perhitungan Daya Sepeda Motor Setelah Modifikasi}

Tabel 2. pengukuran pada saat mesin sesudah dimodifikasi

\begin{tabular}{|l|l|l|}
\hline No & \multicolumn{1}{|c|}{ Item } & \multicolumn{1}{|c|}{$\begin{array}{c}\text { Nilai } \\
\text { Pengukuran } \\
(\mathbf{m m})\end{array}$} \\
\hline 1 & Diameter piston & $50 \mathrm{~mm}$ \\
\hline 2 & $\begin{array}{l}\text { Panjang langkah } \\
\text { torak (TMB) }\end{array}$ & $53,5 \mathrm{~mm}$ \\
\hline 3 & $\begin{array}{l}\text { Panjang langkah } \\
\text { torak (TMA) }\end{array}$ & $3 \mathrm{~mm}$ \\
\hline 4 & Rasio kompresi & $17,33: 1$ \\
\hline 5 & Putaran & $9000 \mathrm{rpm}$ \\
\hline 6 & $\begin{array}{l}\text { Konsumsi bahan } \\
\text { bakar }\end{array}$ & $50 \mathrm{~mL}$ \\
\hline 7 & Waktu pengujian & $426 \mathrm{det}$ \\
\hline
\end{tabular}

Volume ruang bakar/volume maksimum (saat piston posisi TMB),

$$
\begin{aligned}
\mathrm{V}_{\text {Lmak }} & =\frac{\pi}{4} \cdot \mathrm{D}^{2} \cdot \mathrm{L} \\
\mathrm{V}_{\text {Lmak }} & =\frac{\pi}{4} \cdot 50^{2} \mathrm{~mm} \cdot 53,5 \mathrm{~mm} \\
\mathrm{~V}_{\text {Lmak }} & =104993,75 \mathrm{~mm}^{3} \\
\mathrm{~V}_{\text {Lmak }} & =104,9 \mathrm{~cm}^{3}
\end{aligned}
$$

\section{Volume ruang bakar/volume minimum} (saat piston posisi TMA)

$$
\begin{aligned}
& \mathrm{V}_{\text {Lmin }}=\frac{\pi}{4} \cdot \mathrm{D}^{2} \cdot \mathrm{L} \\
& \mathrm{V}_{\text {Lmin }}=\frac{\pi}{4} \cdot 50^{2} \mathrm{~mm} \cdot 3 \mathrm{~mm} \\
& \mathrm{~V}_{\text {Lmin }}=5883,5 \mathrm{~mm}^{3} \\
& \mathrm{~V}_{\text {Lmin }}=5,88 \mathrm{~cm}^{3}
\end{aligned}
$$

Perbandingan kompresi,

$$
\begin{aligned}
& r=\frac{V \max }{V \min } \\
& r=\frac{104993,75 \mathrm{~mm}}{5883,5 \mathrm{~mm}} \\
& r=17,33
\end{aligned}
$$

Perbandingan kalor spesifik udara pada volume tetap,

$$
\begin{aligned}
\mathrm{k} & =\frac{\mathrm{C}_{\mathrm{p}}}{\mathrm{C}_{\mathrm{v}}} \\
\mathrm{k} & =\frac{1,005}{0,718} \\
\mathrm{k} & =1,39
\end{aligned}
$$

\section{Efesiensi thermal,}

$$
\begin{aligned}
& \eta_{\text {th. }}=1-\frac{1}{\mathrm{r}^{\mathrm{k}-1}} \\
& \eta_{\text {th. }}=1-\frac{1}{17,33^{1,39-1}}
\end{aligned}
$$

$\eta_{\text {th. }}=0,6713$

\section{Tekanan Efektif rata-rata}

- Konsumsi Bahan Bakar (BFC)

$$
\begin{aligned}
& \mathrm{BFC}=\frac{\mathrm{vf}(\mathrm{mL})}{t(\text { det })}\left\{\frac{3600(\text { det })}{1(\mathrm{jam})}\right\} \cdot\left(\frac{1 \mathrm{~L}}{1000 \mathrm{~mL}}\right) \\
& \mathrm{BFC}=\frac{50 \mathrm{~mL}}{426 \text { det }} \cdot \frac{3600}{1000} \\
& \mathrm{BFC}=\frac{180000 \mathrm{~L}}{426000 \mathrm{jam}} \\
& \mathrm{BFC}=0.42 \mathrm{~L} / \mathrm{jam}
\end{aligned}
$$

- Laju aliran massa bahan bakar

$$
\begin{aligned}
& \mathrm{m}=\underline{\mathrm{BFC}} \cdot \underline{\rho} \\
& \mathrm{m}=1000 \\
& \mathrm{~m}=1,167^{-4} \mathrm{~L} / \mathrm{det} \cdot 0,68 \mathrm{~kg} / \mathrm{dm}^{3} \\
& =7,934.10^{-5} \mathrm{~kg} / \mathrm{s}
\end{aligned}
$$

- Panas yang masuk ke dalam pembakaran $\mathrm{Q}_{\text {in }}=\mathrm{LHV} \cdot \mathrm{m} \cdot \mathrm{t}$

$\mathrm{Q}_{\text {in }}=44400 \mathrm{~kJ} / \mathrm{kg} \cdot 7,934.10^{-5} \mathrm{~kg} / \mathrm{s} \bullet 426$ det

$\mathrm{Q}_{\text {in }}=1500,5 \mathrm{~kJ}$

- kerja bersih per-siklus,

$$
\begin{aligned}
& \mathrm{W}_{\text {net }}=\Pi_{\text {th }} \bullet \mathrm{Q}_{\text {in }} \\
& \mathrm{W}_{\text {net }}=0,6713 \cdot 1500,5 \mathrm{~kJ} \\
& \mathrm{~W}_{\text {net }}=1007,2 \mathrm{~kJ}
\end{aligned}
$$

- Tekanan efektif rata-rata 


$$
\begin{aligned}
& \mathrm{P}_{\mathrm{e}}=\frac{\text { Wnet }}{\mathrm{Vs}} \\
& \mathrm{P}_{\mathrm{e}}=\frac{1007,2 \mathrm{~kJ}}{99,02 \mathrm{~cm} 3} \\
& \mathrm{P}_{\mathrm{e}}=10,17 \mathrm{kN} / \mathrm{cm}^{2}
\end{aligned}
$$

\section{Daya Spesifik Motor,}

$$
\begin{aligned}
\mathrm{Ne} & =\frac{\mathrm{P}_{\mathrm{e}} \cdot \mathrm{V}_{\mathrm{L}} \cdot \mathrm{a} \cdot \mathrm{n} \cdot \mathrm{z}}{450000} \\
\mathrm{Ne} & =\frac{10170 \mathrm{~kg} / \mathrm{cm}^{2} \cdot 104,9 \mathrm{~cm}^{3} \cdot 1 / 2.9000 .1}{450000}
\end{aligned}
$$$$
\mathrm{Ne}=10668 \mathrm{PS}
$$

\section{Konsumsi Pemakaian Bahan Bakar}

Tabel 3 Perbandingan konsumsi bahan bakar sebelum dan sesudah modifikasi pada pengujian road test

\begin{tabular}{|c|c|c|c|}
\hline $\begin{array}{c}\text { Kecepatan } \\
\mathrm{Km} / \text { jam }\end{array}$ & Pengujian & $\begin{array}{c}\text { Sesudah } \\
\text { modifikasi } \\
(\mathrm{ml})\end{array}$ & $\begin{array}{c}\text { Sebelum } \\
\text { modifikasi } \\
(\mathrm{ml})\end{array}$ \\
\hline \multirow{2}{*}{50} & 1 & 50 & 48 \\
\cline { 2 - 4 } & 2 & 49 & 45 \\
\cline { 2 - 4 } & 3 & 51 & 49 \\
\hline \multicolumn{2}{|c|}{$\begin{array}{c}\text { Nilai rata-rata bahan bakar } \\
\text { yang dipakai (ml) }\end{array}$} & $\mathbf{5 0}$ & $\mathbf{4 7 , 3 3}$ \\
\hline
\end{tabular}

Persentase Konsumsi bahan bakar road test sesudah modifikasi dibandingkan sebelum modifikasi :

Konsumsi BB $=\frac{50-47,33}{50} \times 100 \%$

Konsumsi $\mathrm{BB}=5,34 \%$

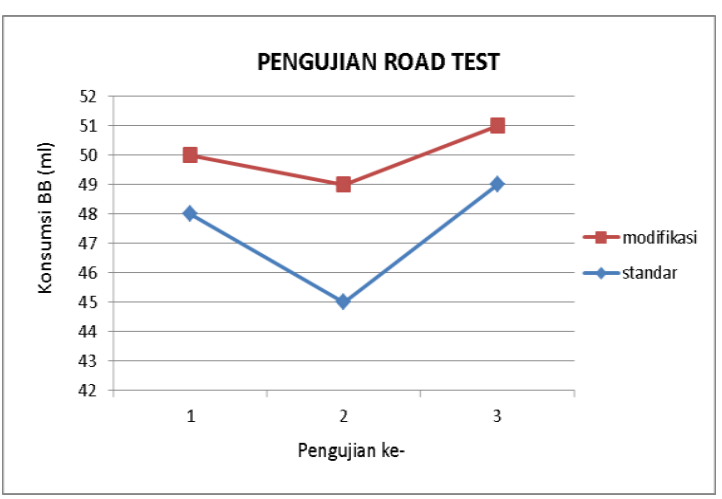

Gambar 3. grafik perbandingan konsumsi bahan bakar antara sebelum dan sesudah modifikasi pada Pengujian Road Test Pada gambar 3, terlihat bahwa pada pengujian road test, memperpanjang langkah torak sepanjang $2 \mathrm{~mm}$ terbukti bahwa konsumsi bahan bakar mengalami peningkatan mencapai $2 \mathrm{ml}$ pada pengujian ke-1, 4 ml pada pengujian ke- 2 dan $2 \mathrm{ml}$ pada pengujian ke-3 dengan jarak tempuh $1 \mathrm{~km}$. Modifikasi memperpanjang langkah torak (stroke) terbukti mempengaruhi konsumsi bahan bakar. Perbandingan konsumsi bahan bakar yang ditunjukkan Pada gambar 3 juga terlihat bahwa pada modifikasi ini sangat efektif karena perbedaan konsumsi bahan bakar yang tidak terlalu besar walaupun volume ruang mesin lebih besar.

Tabel 4 Perbandingan konsumsi bahan bakar sebelum dan sesudah modifikasi pada pengujian stasioner

\begin{tabular}{|c|c|c|c|c|c|}
\hline $\begin{array}{c}\text { Putara } \\
\mathrm{n} \\
\begin{array}{c}\text { Mesin } \\
(\mathrm{rpm})\end{array}\end{array}$ & $\begin{array}{c}\text { Penguji } \\
\text { an Ke }\end{array}$ & \multicolumn{2}{|c|}{$\begin{array}{c}\text { Jumlah Bahan Bakar } \\
\text { (liter) }\end{array}$} & \multicolumn{2}{c|}{ Jumlah Rata-rata } \\
\cline { 3 - 6 } & & $\begin{array}{c}\text { Sebelum } \\
\text { modifika } \\
\text { si }\end{array}$ & $\begin{array}{c}\text { Sesudah } \\
\text { Modifika } \\
\text { si }\end{array}$ & $\begin{array}{c}\text { Sebelum } \\
\text { modifika } \\
\text { si }\end{array}$ & $\begin{array}{c}\text { Sesudah } \\
\text { Modifika } \\
\text { si }\end{array}$ \\
\hline 1500 & 1 & 48 & 50 & 47,66 & 50,66 \\
\hline & 2 & 45 & 49 & & \\
\hline & 3 & 50 & 53 & & \\
\hline 2500 & 1 & 52 & 54 & 55,66 & 57,66 \\
\hline & 2 & 58 & 59 & & \\
\hline & 3 & 57 & 60 & & 74 \\
\hline 4000 & 1 & 71 & 72 & 72 & \\
\hline & 2 & 71 & 76 & & \\
\hline & 3 & 74 & 74 & & \\
\hline
\end{tabular}

Persentase pengujian bahan bakar stasioner sesudah modifikasi dibandingkan sebelum modifikasi :

Konsumsi BB $=\frac{60,77-58,44}{58,44} \times 100 \%$

Konsumsi BB $=3,9 \%$

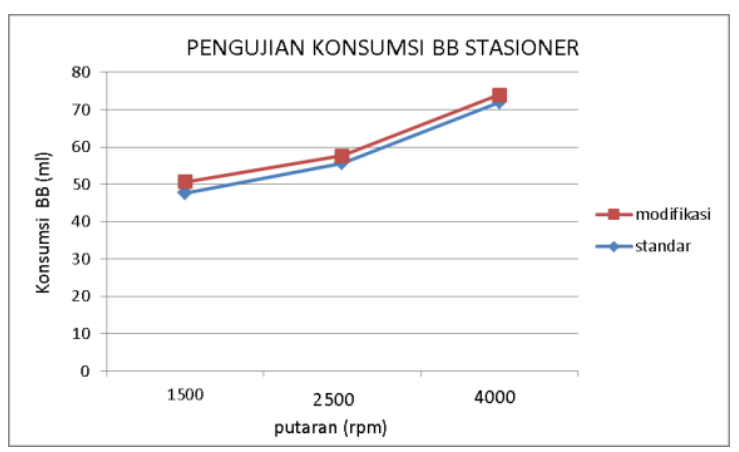

Gambar 4. grafik peningkatan bahan bakar antara sebelum dan sesudah modifikasi pada pengujian stasioner

Pada Gambar 4, terlihat juga konsumsi bahan bakar pada saat pengujian stasioner hampir tidak berbeda jauh dengan gambar 3 yaitu grafik konsumsi bahan bakar pada saat pengujian road test. Grafik pada Gambar 4 menunjukkan bahwa pada kondisi stasioner, 
konsumsi bahan bakar hampir tidak berbeda jauh, yaitu hanya sekitar lebih kurang $2 \mathrm{ml}$ atau dalam persentase tidak lebih dari 5\%, baik pada putaran $1500 \mathrm{rpm}, 2500 \mathrm{rpm}$ maupun $4000 \mathrm{rpm}$.

Dari hasil perhitungan diawal pembahasan terlihat bahwa daya motor yang dihasilkan sebelum dimodfikasi yaitu 8009 PS sedangkan daya motor sesudah modifikasi yaitu sebesar 10668 PS. Sehingga selisih daya yang dihasilkan motor antara sebelum modifikasi dan setelah modifikasi cukup signifikan yaitu sebesar 2659 PS. Artinya modifikasi yang dilakukan membuat mesin motor menjadi lebih bertenaga namun secara ekonomis menguntungkan karena hemat bahan bakar.

\section{Pengujian Akselerasi}

Tabel 5. Data Akselerasi pada Pengujian Road Test akselerasi

\begin{tabular}{|c|c|c|c|c|c|c|c|c|}
\hline \multirow{4}{*}{$\begin{array}{l}\text { Kecepatan } \\
(\mathrm{km} / \mathrm{jam})\end{array}$} & \multirow{2}{*}{\multicolumn{6}{|c|}{$\begin{array}{c}\text { Waktu } \\
\text { Modifikasi }\end{array}$}} & \multirow{2}{*}{\multicolumn{2}{|c|}{$\begin{array}{c}\text { Rata-rata waktu } \\
\text { yang diperoleh }\end{array}$}} \\
\hline & & & & & & & & \\
\hline & \multicolumn{3}{|c|}{ Sebelum } & \multicolumn{3}{|c|}{ Sesudah } & \multirow[t]{2}{*}{ sebelum } & \multirow[t]{2}{*}{ Sesudah } \\
\hline & 1 & 2 & 3 & 1 & 2 & 3 & & \\
\hline $0-20$ & 3 & 3 & 3 & 3 & 3 & 3 & 3 & 3 \\
\hline $0-40$ & 6 & 6 & 6 & 6 & 6 & 6 & 6 & 6 \\
\hline $0-60$ & 12 & 11 & 12 & 10 & 10 & 10 & 11,6 & 10 \\
\hline $0-80$ & 20 & 20 & 20 & 17 & 17 & 17 & 20 & 17 \\
\hline
\end{tabular}

Gambar 5. grafik perbandingan akselerasi antara sebelum dan sesudah modifikasi

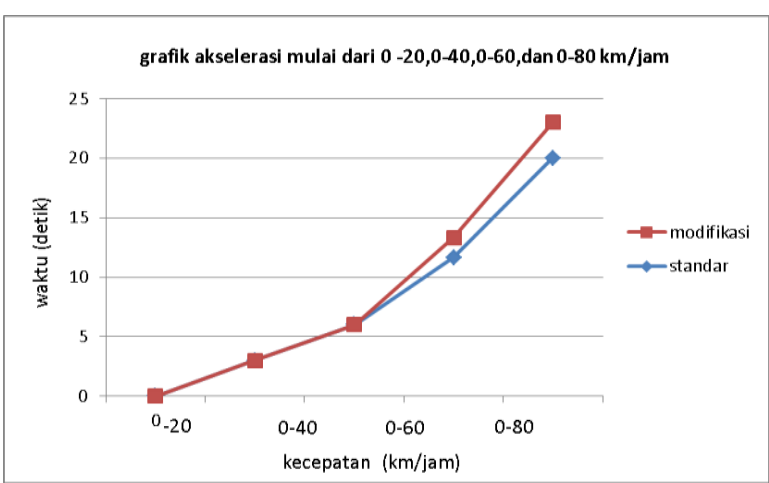

terhadap waktu tempuh

Pada gambar 5, menunjukan pada kecepatan 0-20 km/jam dan 0-40 km/jam antara mesin standard dan modifikasi waktu tempuh yang di peroleh sama yaitu samasama memperoleh waktu tempuh 3 detik pada kecepatan 0-20 km/jam dan pada jarak 0-40 $\mathrm{km} / \mathrm{jam}$ sama-sama memperoleh waktu tempuh 6 detik sehingga tidak ada perbedaan antara standard dan modifikasi, dan pada kecepatan 0-60 km/jam pada mesin standard dapat di tempuh dengan waktu 11,66 detik dan pada mesin modifikasi dari $0-60 \mathrm{~km} / \mathrm{jam}$ dapat ditempuh dengan waktu 10 detik, penurunan waktu tempuh mencapai 1,66 detik. Pada kecepatan 0-80 km/jam pada mesin standard dapat ditempuh dengan waktu 20 detik dan pada mesin modifikasi dari 0-80 $\mathrm{km} / \mathrm{jam}$ dapat di tempuh dengan waktu 17 detik penurunan waktu tempuh mencapai 2 detik.

\section{E. Pengujian Kecepatan Maksimum}

Tabel 6. Data kecepatan maksimum kendaraan sebelum dan sesudah modifikasi pada Pengujian road test

\begin{tabular}{|c|c|c|c|c|c|}
\hline $\begin{array}{c}\text { Dimensi } \\
\text { mesin }\end{array}$ & $\begin{array}{c}\text { Pengujia } \\
\mathrm{n} \mathrm{ke}-\end{array}$ & $\begin{array}{c}\text { Kecepata } \\
\mathrm{n} \\
(\mathrm{km} / \mathrm{jam})\end{array}$ & $\begin{array}{c}\text { Putara } \\
\mathrm{n} \\
(\mathrm{rpm})\end{array}$ & $\begin{array}{c}\text { Waktu } \\
\text { tempu } \\
\mathrm{h} \\
(\mathrm{detik})\end{array}$ & $\begin{array}{c}\text { Jarak } \\
\text { tempu } \\
\mathrm{h}(\mathrm{km})\end{array}$ \\
\hline \multirow{3}{*}{ Standard } & 1 & 97 & 8000 & 430 & 1 \\
\cline { 2 - 6 } & 2 & 97 & 8020 & 425 & 1 \\
\cline { 2 - 6 } & 3 & 99 & 8400 & 430 & 1 \\
\hline \multirow{2}{*}{$\begin{array}{c}\text { Modifikas } \\
\mathrm{i}\end{array}$} & 1 & 103 & 9000 & 380 & 1 \\
\cline { 2 - 6 } & 2 & 100 & 9000 & 360 & 1 \\
\cline { 2 - 6 } & 3 & 105 & 9200 & 390 & 1 \\
\hline
\end{tabular}

Pengujian tersebut menghasilkan kecepatan $97 \mathrm{~km} / \mathrm{jam}$ dan putaran $6000 \mathrm{rpm}$ dengan waktu tempuh 430 detik pada posisi mesin standard, dan pengujian yang ke-dua yaitu dengan keadaan mesin yang sudah dimodifikasi menghasilkan kecepatan103 $\mathrm{km} / \mathrm{jam}$ dan putaran $7000 \mathrm{rpm}$ dengan waktu tempuh 380 detik.

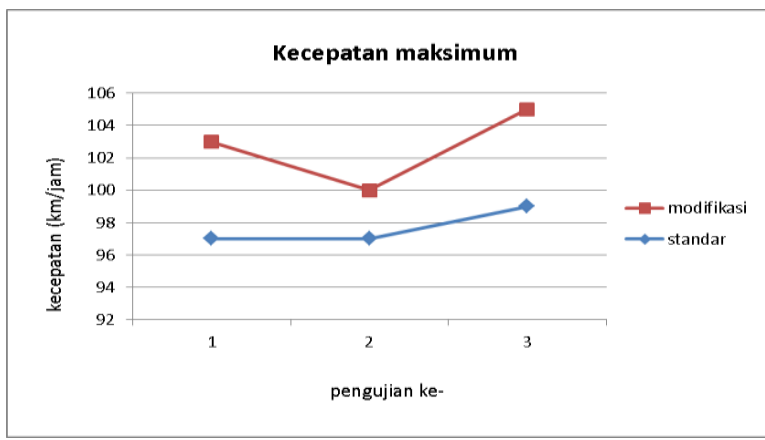

Gambar 6.Grafik pengujian kecepatan maksimum terhadap waktu tempuh dengan jarak tempuh $1 \mathrm{~km}$.

Pada Gambar 6, terlihat peningkatan kecepatan dari keadaan standard dan modifikasi mencapai $6 \mathrm{~km} / \mathrm{jam}$ dengan penurunan waktu tempuh 50 detik. Dari uraian di atas dari pengujian bahan bakar mengalami peningkatan konsumsi bahan bakar dan bertambah juga pada akselerasi dan 
kecepatan maksimum. Modifikasi memperpanjang langkah torak efesien untuk digunakan sehari-hari maupun untuk keperluan jasa angkutan yang lain.

\section{Kesimpulan}

Berdasarkan data-data hasil pengujian antara mesin standard dan modifikasi terhadap prestasi sepeda motor 4 langkah 110 cc, didapat beberapa simpulan sebagai berikut

1. Setelah dilakukan perhitungan antara mesin modifikasi memperpanjang volume langkah torak dari standar sebesar 97,1 $\mathrm{cm}^{3}$ dengan daya 8009 PS sebelum dimodifikasi, dan setelah dimodifikasi menjadi menjadi $104,9 \mathrm{~cm}^{3}$ dengan daya 10668 PS sehingga mengalami peningkatan volume ruang bakar sebesar $7,8 \mathrm{~cm}^{3}$ dan daya sebesar 2659 PS.

2. Modifikasi stroke (memperpanjang langkah torak) mampu meningkatkan efesiensi thermal mesin, sebelum modifikasi sebesar 0,5756 dan setelah modifikasi mencapai 0,6713.

3. Didalam modifikasi ini konsumsi bahan bakar berdasarkan pengujian road test sebelum modifikasi 47,33 mL meningkat menjadi $50 \mathrm{~mL}$ sesudah dimodifikasi dan pada pengujian stasioner sebelum dimodifikasi $72 \mathrm{~mL}$ meningkat menjadi 74 $\mathrm{mL}$ sesudah dimodifikasi dikarenakan volume ruang bakar yang bertambah dan membutuhkan konsumsi bahan bakar yang lebih banyak.

\section{Referensi}

[1] Robertus Simanungkalit, Tulus B. Sitorus, 2013, Performansi Mesin Sepeda Motor Satu Silinder Berbahan Bakar Premium dan Pertamax Plus dengan Modifikasi Rasio Kompresi, Jurnal E-Dinamis, Vol. 6, No. 1.

[2] A. Setyawan, 2007, Pengaruh Ignition Timing dan Compression Ratio terhadap Unjuk Kerja dan Emisi Gas Buang Motor Bensin Berbahan Bakar Campuran Etanol 85\% dan Premium, Seminar Nasional Teknologi 2007, p3m.Amikom.ac.id
[3] I Muku, IGK Sukadana, 2009, Pengaruh Rasio Kompresi terhadap Unjuk Kerja Mesin Empat Langkah Menggunakan Arak Bali sebagai Bahan Bakar, Jurnal Ilmiah Teknik Mesin Cakra M, Hal. 2632

[4] Arismunandar, Wiranto. 1983. Penggerak mula motor bakar torak. Teknik Mesin. ITB. Bandung

[5] Hidayat, Wahyu. 2012. Motor bensin modern. Teknik Mesin. Rineka cipta. Jakarta

[6] Cengel, A, Yusuf, Boles, A, Micheal. 2005. Thermodynamics An Enginering Approach. Fifth Edition, E-Book.

[7] Kurniawan, Riski. 2008. Perhitungan prestasi mesin motor bakar 4-langkah. Teknik Mesin Universitas Indonesia.

[8] Effendi, Mario. 2003. Perhitungan Parameter Prestasi Mesin. Teknik Mesin UNIVERSITAS SUMATRA UTARA. 